\title{
RECENZIÓ \\ RADVÁNYI KATALIN „A LEGBELSŐ KÖR: A CSALÁD” CÍMŰ KÖNYVÉRŐL
}

\author{
A recenzió szerzője: \\ Horváth Brigitta \\ (Magyarország) \\ A szerző e-mail címe: \\ hbrigitta89@gmail.com
}

Horváth Brigitta (2019): Recenzió - Radványi Katalin „A legbelső kör: a család” címú könyvéről. Különleges Bánásmód, 5. (4). 71-78. DOI 10.18458/KB.2019.4.71

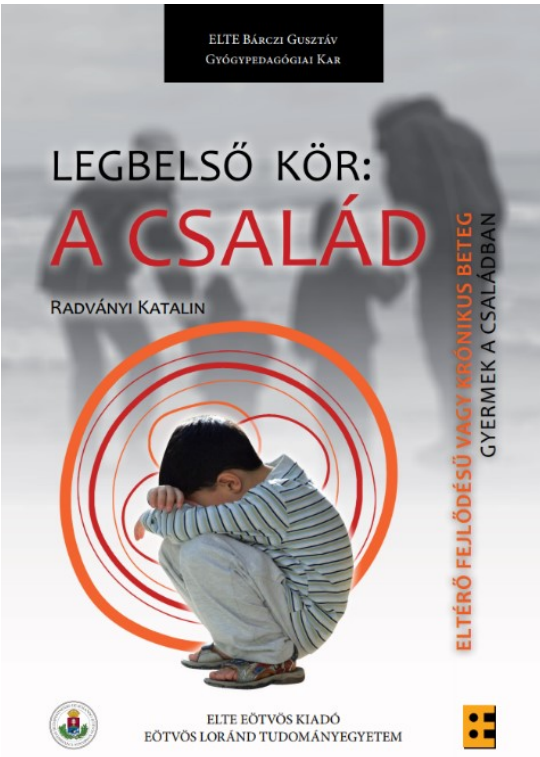

A gyógypedagógiai nevelés során a legtöbb esetben felmerül az egyik legfontosabb kérdéskör: a sérült gyermekhez és a családjához való viszonyulás és szakszerű segítés. Mivel a család a szocializáció elsődleges - és így a legjelentősebb - közege, a közvetlen rokonokkal és a tágabb környezettel való megfeleló kapcsolattartás elengedhetetlen, hiszen a fejlesztés is csak abban az esetben lehet hosszútávon eredményes, ha a családtagok és a pedagógusok, nevelők közötti kapcsolat megfeleló, a kapcsolattartás folyamatos. Ez a szempont az egyetemeken is oktatott egyik legjelentősebb dimenzió egy gyógypedagógus számára a munkája során, ám a „másik oldalról” sok esetben kevés szó esik. Nevezetesen arról, hogy a nukleáris család hogyan éli meg a fogyatékos gyermekkel való együttélést, hogyan tudnak a családtagok egymáshoz viszonyulni, egyáltalán elfogadni gyermekük állapotát? Megértik-e a szülők, hogy a gyermek „tanítójuk” lehet az életben, túl mernek-e tekinteni, a mindennapi nehézségeken felül tudnak-e emelkedni a gyermek gondozói? Fenn tudják-e tartani a családi harmóniát, egyensúlyt, van-e külső segítségük és idôt tudnak-e szakítani saját rekreációjukra és mentálhigiénés jóllétükre? A fogyatékos vagy krónikus beteg gyermek 
„más”, törvényszerűen „kilóg a sorból”, ezáltal a család is nemegyszer magára vonja a kívülállók figyelmét. Ez eleinte okozhat a szülők számára kellemetlen szituációkat, ám az empátia, a tolerancia, az altruizmus készségének elsajátításával ezeken túl lehet, és túl is kell tekinteni.

Sok esetben meg kell tanulni a családnak elfogadni a szakszerû és a mindennapi segítséget ahhoz, hogy a családi élet viszonylagos egyensúlya ne boruljon fel olyannyira, hogy ez a család széteséséhez vezessen. Az édesapa sajnos nem egy esetben elhagyja a családot, ha fogyatékos, beteg gyermek születik a családba, és ez a szituáció a felelősségvállalást teljes egészében az édesanyára hárítja.

Hazánkban probléma az, hogy nincsen kiépített megsegítő, mentálhigiénés hálózat a családtagok számára, illetve formálisabb közösségek, ahol a hasonló helyzetben élő családok fórumokat tudnának létrehozni. Ezek nagyban hozzájárulhatnának a feszültségek levezetéséhez és a mindenkori problémás kérdések megválaszolásához. Szakemberi (mediátori) segítséggel már sok civil kezdeményezés született, de társadalombiztosítási alapon a megfelelő, szakszerú, megfelelő időben történő pszichés megsegítés még várat magára. Szociális szempontból tehát beszélni kell az ilyen helyzetben lévő családokról, ôk társadalmunk szerves részei, az ô problémáik túlmutat saját életükön, hiszen a szociális és az egészségügyi szférán túl az egész pedagógus társadalom is találkozik a kérdéskörrel.

Radványi Katalin könyvében írja, hogy az utóbbi években szerencsére már több olyan kiadvány is megjelent, melyek „foglalkoznak az eltérő fejlődésű vagy krónikusan beteg gyermeket nevelő családokra jellemző problémákkal” (Radványi, 2013, 7.).

$\mathrm{Az}$ érintett családoknak számít más emberek jelenléte, a felelősség megosztása. Szenzitív kérdés, hogy a külvilág mennyire reagál érzékenyen a bajba jutott emberekre, van-e valódi segítség vagy a negatív reakciók vannak-e túlsúlyban. Kétségtelen, hogy a család a társadalmi részvételre történő felkészítés legfontosabb közege. A társadalom és a szakemberek feladata, hogy a társadalmi érzékenységet és a segítségnyújtás mértékét növelje. 2011-ben kiadták a Ritka rendellenességek diagnórisközlésének protokollját, melynek jelentős hiánypótló szerepe van Magyarországon.

A megfelelő környezeti feltételek közé sorolhatók a jól múködő személyek, fóleg a családon belül az anya, és a gyermek vele való kapcsolata kiemelendő. Azonban az édesanyára hatással van a tágabb környezet. Így az utóbbi évtizedekben az anya szerepének hangsúlyozása mellett fontossá vált a családtagok, a családi dinamika vizsgálata is.

„A jól múködő családnak a pszichés megbetegedések szempontjából preventív szerepe van." (Radványi, 2013, 10.) Mindennek az alapja a társas támogatás. Mivel az eltérő fejlődésú gyermek születése a családban akcidentális, hirtelen történő krízist okoz, nincsenek társadalmilag hagyományozódó megküzdési technikák, módok. A csökkent mentális vagy fizikai funkciók közé soroljuk például az asztmát, a diabéteszt, az epilepsziát, az idegrendszeri károsodást, az értelmi fogyatékosságot, a mozgássérülést. Ilyen betegségek esetében zavar állhat be a szülő és a gyermek kapcsolatában, mely további nehézséget jelenthet a szocializációban. (11.) A szülőkben ott él a vesztség, a gyász érzése, melyet a várt, de meg nem született gyermek hiánya okoz. Rendkívül fontos lenne az azonnal megkezdődő pszichés támogatás folyamata. A szülőkben lejátszódó gyászfolyamat lehet az első pszichológiai tanácsadás témája, hiszen a szülők „búcsút” kell, hogy vegyenek attól a gyermektől, akit korábban elképzeltek. A folyamat fázisai általánosan leírhatók, az egyéni feldolgozás üteme azonban egyéni. Az anyák emocionális reakciója tovább tart, mint az apáké, mely további családi problémákhoz vezethet oly módon, hogy a feleség érzelmi támaszt keres férjében, aki viszont sok esetben ezt nem tudja a várt mértékben megadni, melynek következtében ő inkább szakmai munkája felé orientálódik. (Radványi, 2013, 115.)

A fogyatékos gyermek születése kiemelt hatással van a családi múködésre. Az épen fejlődő gyermekhez képest a fogyatékos gyermek jelentős megterhelést okozhat a családi dinamika valamennyi résztvevője számára, illetve mindez visszahat a gyermek fejlödésére is a tranzakcionális elmélet értelmében. (49-50.) A fogyatékosság tényével való szembesülés krízishelyzetet okoz a családban. A gyermek elfoga- 
dására vagy elutasítására hatással van a környezet hozzáállása, a fogyatékossággal kapcsolatos attitűd, és ezek a krízis mélységét, tartósságát, feloldhatóságát nagymértékben befolyásolhatják. Számos beszámoló alapján elmondható, hogy eltérő fejlődésű gyermek érkezése a család fejlődését késlelteti, lefékezi a családi életritmust. A hagyományos „családi életciklussal” szemben (illetve mellett) McKeith (1973) fő válságidőszakokat jelöl meg. Az első akkor jelentkezik, mikor kiderül a gyermek fogyatékossága, a második, amikor a gyermek speciális szolgáltatásokat kap, a harmadik az az időszak, mikor a gyermek elhagyja otthonát és az iskolát, „leválik” a szülőkről és megjelennek önállósulási igényei. Felfedezhetők a családi instabilitás jelei, illetve egyes felmerülő problémák csökkentik a családi összetartozást (Farber, 1975). Alábbiak közé tartozik, hogy a gyermek csak csökkent képességgel tud kölcsönös tevékenységekben részt venni, mely redukálja a kommunikációt és a családtagok kompetenciaérzését. A gyermeknek nagyobb a függőségi igénye, mely önmagában is megterhelő a család számára, hiszen ez a többi közös tevékenységtől vonja el az energiát. A társadalmi érintkezések is csökkenhetnek. A családtagoknak el kell viselniük törekvéseik szimbolikus halálát, illetve a megváltozott igények másfajta viselkedést követelnek a családtagoktól (Radványi, 2013, 52.)

A szülők, a család által megélt gyászfolyamat -, melyet a gyermek fogyatékosságának tudomásul vétele magával hoz - fázisokból, szintekből áll. A releváns tanulmányok felsorolják a stádiumok jellemzőit és a pszichológiai hozzáállás lehetőségeit. A folyamat sikerességét mutatja az a kimenet, mely a helyzet tudatos elfogadását jelenti (Radványi, 2013, 72.).

A gyermek szocializációját és fejlődését már a megszületéstől kezdve befolyásolják bizonyos tényezők, úgy mint a gyermek fizikai mássága, a születés körüli problémák. A diagnózis közlése nyomán sokkos állapotba kerülhetnek a szülők. A normál gyász időtartamát általában egy évnek tekinthetjük, a patológiás gyászreakció-típusok egyik formája a kései gyászreakció. Amennyiben rögtön születés után kiderül a fogyatékosság, az anyának a terhesség alatt már kialakulhatott a kötődése a gyermekhez, az apának kevésbé. Mivel a gyászreakció nem halálesettel párosul, nincs látható veszteség, „nem illik” sírni. Nincsenek társadalmilag kialakult rítusok erre a fajta gyászfolyamatra. Sok esetben hiányzik a szociális dimenzió, a közösség támogatása, a társadalmi intézményformák. Mivel a feldolgozás során a gyermek jelen van, foglalkozni kell vele, a szülők saját mentálhigiénés problémáira kevesebb idő, energia jut. (Radványi, 2013, 69-70.)

Az eltérő fejlődésű gyermekekkel foglalkozó vizsgálatok sokáig nagyrészt csak a gyermekre, illetve az anya-gyermek kapcsolatra koncentráltak, és csak az 1970-es évektől kezdődően fordult az érdeklődés a család működésében részt vevő személyek és hatásrendszerek vizsgálata felé. Gallagher és Bristol (1989;1992) erre hívják fel a figyelmet, leírva a családi kapcsolatrendszerek dinamikus jellemzőit.

A közhiedelem szerint nagy valószínűsége van annak, hogy a szülők elválnak, ha fogyatékos gyermekük születik. Ezzel szemben a vizsgálatok alapján az feltételezhető, hogy valójában csak abban az esetben következik be válás, ha a szülők kapcsolata egyébként is labilis volt. Jó párkapcsolatnál a gyermekkel kapcsolatos problémák inkább az összefogást, összetartozást erősítik meg. Az apáknak a fogyatékos gyermekük nevelésében betöltött szerepével az 1970-es évekig szintén alig foglalkoztak a kutatások. Az anyáknak nagyobb szerepet tulajdonítanak a gyermeknevelésben.

Ma már az apaság jelentősége egyre világosabb, maguk az apák is részt kívánnak venni a sérült gyermek nevelésében. A hagyományosan múködő családban a gyerekkel játszótársi szerepet töltenek be, a gyermek eltérő fejlődése esetén azonban ez a folyamat kevésbé sikeres, mivel nem tudják, mikor, mit és hogyan játszhatnak gyermekükkel, szerepükben elbizonytalanodnak (Radványi, 2013, 62-63.).

Azokban a családokban, ahol fogyatékos kisgyermek van, a megnövekedett terheket általában aránytalanul az anyák viselik. Azok az apák, akiknek fogyatékos gyermekük van, általában nem segítenek többet a gondozásban, mint más apák (Radványi, 2013, 55.).

Az 1970-es évektől kezdődően a kisgyermek fejlődését befolyásoló tényezőket az úgynevezett „tranzakcionális modell” keretében értelmezzük, melynek kiindulópontja, hogy a gyermek a születéstől 
fogva hat a környezetére (Dallos-Procter, 1989 In Mérei F., 1990. 7-50.). A szülőket a folyamatba be kell vonni, de a felelősséget nem szabad rájuk hárítani. Fontos, hogy a szülő kompetens szülőként élhesse meg ezt az időszakot (Radványi, 2013,56.). Fogyatékossággal élő gyermekek esetében a szülő oldaláról a pszichés terhek miatt sérülhet az érzékenység a gyermek felé, elfogadása sem annyira nyilvánvaló. A családban a társas támogatás különböző formáinak is különös hangsúlya van sérült gyereket nevelő szülőknél.

A fogyatékos gyermek korai viselkedéses megnyilvánulásokban olyan eltéréseket mutat, melyek nem könnyítik meg az anya/gondozó helyzetét. Ezek lehetnek a szemkontaktus, a szociális mosoly, szociális érdeklődés és a pozitív érzelmek kifejezésének atipikussága vagy hiánya, gyengébb válaszkészség a szülői kezdeményezésekre (Zwaigenbaum et al. 2005) és az esetleges nehéz temperamentum. A gyermek jelentôs fizikai és kognitív sérüléseinél a korai kötődés személyiségfejlődést befolyásoló tényezői torzulhatnak (Kulcsár, 1996; Radványi, 1999). Az „eltérő fejlődés”, „fogyatékosság” vagy „krónikus betegség” esetén nem beszélhetünk egységes jellemzôkről. Bár sérült gyerekek és anyáik között nagyobb a problémák előfordulásának kockázata, de önmagában az értelmi fogyatékosság vagy autizmus ténye nem indokol rossz minőségú anya-gyermek kapcsolatot vagy bármiféle negatív következményt. A kutatások alapján a gyermeknél észlelt dominancia sem értelmileg akadályozott, sem autista gyermekeknél nem befolyásolta az anyai kontrollálás, túlvédés mértékét. Sokszor előfordul, hogy a szülő rejtett búntudata, ambivalens érzelmei vagy bizonytalansága miatt nem állít korlátokat, szabályokat a különleges igényú gyermek elé (Radványi, 2013, 62.).

Amennyiben krónikus beteg vagy fogyatékos gyermek van a családban, néhányan a testvéreket fokozottan sebezhetőnek vélik (Gallagher-Bristol, 1989 In Wang, M. C.-Reynolds, M. C.-Walberg, H. J; Fisman et al., 2000), de nem tartják igazoltnak azt a feltevést, amely szerint a fogyatékos gyermek testvéreit elkerülhetetlenül negatív hatások érnék (Wolf et al. 1998; Stoneman, 2005; Shuntermann, 2009). Értelmi fogyatékos gyermekek testvérei köré- ben nagyobb arányban tapasztalták a segitố viselkedést, különösen jellemző volt ez a lányok esetében és a fiatalabb értelmi fogyatékos testvérrel való kapcsolatban. A segités nem pusztán fizikai tevékenységekben, hanem érzelmi támogatásban is megnyilvánult (Hannah-Midlarsky, 2005).

Ma már bio-pszicho-szociális megközelítésben vizsgáljuk az egyént, és megfogalmazhatjuk, hogy a környezet nem statikus, hanem dinamikus, állandóan változó (Radványi, 2013, 12.).

Elméleti szempontból több megközelítés is releváns. Kiemelendő az öröklés-környezet vita, illetve a modern elméletek. Utóbbiak nem egyszerúsítették le a kérdéskört genetikai vagy környezeti tényezőkre. Az interakciós modell megállapítása szerint a fejlődő egyén aktuális állapota mindig az előző állapot és az aktuális környezeti hatások interakciójának eredménye.

A tranzakcionális modell úgy vélekedik, hogy a fejlődő egyént a környezete, így a saját fejlődési feltételeinek aktív szervezőjeként kell tekinteni. A gyermek környezetének vizsgálatánál elég gyorsan használni kezdték a szocioökonómiai változókat.

A környezet szerepe kiemelendő a gyermek fejlődésének tekintetében. Kimutatott tény, hogy amelyik gyermekkel megfelelőképpen foglalkoznak, nőhet az intelligenciaszintje és az önellátásának mértéke. A gondozás minőségének már a legkorábbi időszakban is jelentősége van, előrehaladottabb kognitív-nyelvi funkcionálást eredményez (Radványi, 2013, 21.).

Figyelni kell azonban arra is, hogy a gyermek túlzottan középpontba helyezése is problémákhoz vezethet a viselkedésben. Az 1960-as évek longitudinális vizsgálatai rámutattak, hogy a fejlódés egyéni mintázatai a gyerek és környezet között specifikus tranzakciókat hoznak létre.

A testi tünetek észrevehetősége jobb gyermeki adaptációval jár együtt. Ez azért lehetséges, mert a nehézségek egy szemtanú számára magától értetődőek, nem szükséges indokolni, magyarázni a helyzetet.

A társadalmi-gazdasági helyzet nem áll közvetlen kapcsolatban az adaptáció szintjével sem a gyermeknél, sem a szülóknél, illetve a család méretének, a 
családi állapotnak, a nemi és az etnikai hovatartozásnak sincs jelentősége.

A családi változók, úgy mint a nyílt kommunikáció, a konfliktus hiánya, a családi kohézió, a jobb érzelmi kifejezőkészség, a családi stabilitás előre jelzik a képességet, hogy megbirkózzanak a betegséggel, fogyatékossággal (Radványi, 2013, 56.).

„A gyermekek intelligenciája már 2-3 éves korban pozitívan korrelál a szülők szocioökonómiai státuszával, vagyis minél magasabb a szülők iskolai végzettsége, beosztása, jövedelme, annál intelligensebb a gyermek." (Radványi, 2013, 22.). Kimutatható, hogy a rugalmasan strukturált családi környezet jobban kedvez a gyermek fejlődésének, mint a merev vagy az alig szabályozott. Mivel a fizikai valóságot a szülők közvetítik, nagyon fontos részükről a stimuláció mennyisége, típusa és ideje. Az otthoni környezet szervezettsége is kardinális szereppel bír. A gyermek kognitív és motivációs fejlődésére hatással vannak a megfelelő játékok, azok komplexitása és választékossága. (Radványi, 2013, 25.) A bio-pszichoszociális megközelítés vizsgálja a személy biológiai jellemzőit, illetve a személy és a környezetében élók pszichológiai állapotát, a körülvevő csoportok egymásra hatásait. Bizonyos problémák abból eredhetnek, hogy az átlagostól eltérő fejlődésű gyermekekkel kapcsolatban a szülők nem rendelkeznek nevelési mintákkal, melynek következtében az anya-gyermek kapcsolat torzulhat, ha az anya/szülők nem kapnak mentálhigiénés támogatást. (Radványi, 2013 , 26.) D. O. Hebb hangsúlyozza, hogy lényeges az első két életévben a szenzoros és motoros agyi területek kapcsolata, illetve hogy a korai időszakban mentális elmaradáshoz vezethetnek az extrém deprivációs helyzetek (Radványi, 2013, 27.).

A fejlődő gyermekek számára fontos a források rendelkezésre állása, ám eltérő fejlődés esetén nem elég az átlagos fejlődéshez szükséges optimális feltételek biztosítása, hanem az egyéni kompetenciáknak megfeleló változásokat kell betervezni. A humanökölógiai modell szerint a gyermek és a családja egy nagyobb rendszer része, ahol valamennyi tényezô és rendszer között kapcsolódás lép fel. Kirk és munkatársai a rendszerelméletet eltérő fejlődésû gyermekek esetén is elemezték. Javaslatuk szerint már 5 éves kor előtt meg kell tanítani a szülőket arra, hogyan bánjanak eltérő fejlődésű gyermekükkel, ebben az időszakban ugyanis ôk az ideális tanítók a gyermek számára. A családtagok támogatása tehát éppolyan erőteljes beavatkozás, mintha a gyermekre fókuszálnánk. A család három területen hat az egyéni képességekre: a családi, az iskolai és a társadalmi szinteken. Ha a család nem alkalmaz hatékony instrukciókat, a gyermek jártasságai nem erősödnek. Ha azonban támogató aktivitás nyilvánul meg, az kiegyensúlyozó faktor lehet (Radványi, 2013, 35-38.).

A könyv számba veszi és rámutat országok szerinti tanulmányok eredményeire. Németországban a szubjektív megterheltség mérésérôl kaphatunk információkat, Hollandiában a súlyosan értelmi fogyatékos és halmozottan sérült gyermekek gondozására fordított időről és energiáról. A magyarországi esettanulmány az első időszak történéseit mutatja be a szülők szemszögéből. Az amerikai egyesült államokbeli kutatás ráfókuszál az értelmi fogyatékos apák és anyák hozzájárulására a családi funkcionálás szintjéhez. Egy másik egyesült államokbeli tanulmány pedig a Down-szindrómás gyermekekre és szüleikre koncentrál, nevezetesen a szülői stresszre és a gyermeknevelésre.

Hill és Rogers alkották meg a „családi életciklus modellt”, melynek lényege, hogy a családi kisközösség bizonyos fordulópontokhoz jut az életben, mely során a család és az együttmúködési készség fejlődni tud, az életciklusok közötti átmenet alkalmazkodást igényel. Ennek hiányában normatív krízis alakul ki. A paranormatív vagy akcidentális krízisek ettől függetlenül, hirtelen következhetnek be. (Radványi, 2013, 39.) Komlósi (1992) 9 pontban foglalta össze a betegséggel együtt járó legfőbb stresszforrásokat: a családi kapcsolatok megterhelődése; a családi aktivitás és célok módosulása; a megnövekedett feladatok és az időbeli megkötöttségek terhei; növekvő anyagi terhek; a lakáskörülmények módosításának igénye; társas izoláltság; az orvosi kezeléssel kapcsolatos gondok; iskoláztatási nehézségek; szomorúság. Bowes és Hayes (1999. 37-38.) kutatásai arra az eredményre jutottak, hogy a felső szocioökonómiai státuszú, teljesítményorientált családok „tragikus krízisen” esnek át, amikor gyermekük fogyatékossága egyértelmúvé 
válik. A fogyatékos gyermekek családja az állami támogatások ellenére is anyagi problémákkal szembesülhetnek, illetve fokozottabb szociális izolációról is beszámolnak a felmérések (Radványi, 2013, 42.).

A rizikó- és védőfaktorok szerepe kiemelendő a tekintetben, hogy széles körü vizsgálat alá estek a gyermekek elhanyagolásának, bántalmazásának hátterében húzódó tényezők.

A rizikótényezóket csoportosítva általában az egyénen belül jelentkező, a családi, iskolai, illetve a tágabb közösségben vagy a társadalomban rejlő rizikófaktorok különböztethetők meg. A reziliencia fogalma alatt az a folyamat értendő, mely során a kedvezőtlen környezet ellenére kedvező fejlődési kimenetel mutatkozik. A reziliencia multidimenzionális, beszélhetünk például tanulmányi, érzelmi, viselkedéses rezilienciáról. Több rizikófaktor együttes jelenléte esetén a hatások nem egyszerúen összeadódnak, hanem hatványozottan jelentkezhetnek (Radványi, 2013,44-45.).

Az utóbbi évtizedek kutatásai arra irányultak, hogy a környezet számára is lehetôvé tegyék az elfogadást, fókuszban az egészségügyi szolgáltatásokkal, ahonnan a legtöbb információ és segítség érkezhet. Sajnálatos módon az érintett szülők hiányolják a diagnózis közléséhez tartozó jogaikat. A magyar kutatások mindössze 10\%-ban mutattak ki empatikus diagnózisközlést. (Radványi, 2013, 83.)

Ez utóbbihoz kapcsolódóan említhetôk a diagnózis közléséhez kötődő modellek (Krause, 2005. In Stahl, B-Irblich, D.), melyeket egyébként az onkológiai kezelésekből vettek át. A formális modell lényege, hogy az orvos és a páciens közötti kölcsönös függőség van a középpontban. A diagnoszta számára az okoz nehézséget, hogy őszintén kell közölnie az eredményeket, ám eközben tapintatosnak is kell lennie a szülókkel szemben. A hír hallatán természetszerúleg ambivalens érzelmek mutatkoznak meg, hiszen egyrészt ki kell derülnie a pontos diagnózisnak, másrészt félelem van a szülőkben a betegséggel kapcsolatban, mely a fogyatékosság tényének hárítását eredményezheti. (Radványi, 2013, 105-106.) Egyik ezzel foglalkozó modell a szociolingvisztikai modell, mely azon a tényen alapul, hogy a diagnózis közlésekor a nem egyértelmú fogalomhasználat félreérthető lehet. A Roberts és munkatársai által leírt páciensorvos interakcióban a leglényegesebb elemek közé tartozik az empátia, a távolság, az elméleti szervezés. Gallagher és munkatársai más dimenziókat hangsúlyoznak ki: a rokonszenvet, a jóindulatot, a közelséget, a bizalmat, a nyugalmat, a formaságot és a dominanciát. (Radványi, 2013, 110-111.) A kliensközpontú modell a segítő és a páciens közötti kommunikációt emeli ki. A hierarchikus modellel ellentétben nagy jelentőséget kap az empátia és a nyíltság, magában foglalja a zavartalan és a páciens számára érthető diagnózisközlési lehetőséget. A nemzetközi szakirodalomban is különböző javaslatokat találunk, ám összefoglalóan a két leghangsúlyosabb elem a diagnózisközlésnél az, hogy kompetens személy közölje a betegség tényét, illetve mindkét szülő legyen jelen (Radványi, 2013, 115-116.).

A diagnózisközlés miatt kialakult érzelmi állapotok és a gyermek-szülő kapcsolati nehézségek oldását véli Sarimski a diagnózisközlést követő pszichológiai tanácsadás legfontosabb dimenziójának. A pszichés megsegítés célja a szülői kompetenciák megerősítése, mely közvetve a gyermek fejlesztésére is hatással van, amelynek hiányában egyébként később másodlagos sérülések, elmaradások és szociális nehézségek léphetnek fel (Radványi, 2013, 113.). Sarimski (2003) javaslatokat fogalmaz meg a szülők pszichés támogatásának elősegítése céljából.

A család támogatása a későbbiekben, a családterápia és a családközpontú rendszer tervezése, megvalósítása több szinten történik. A támogatás formái között kell említeni az egészségügyi, a szociális és az oktatásügyi megsegítést. Hazánkban problémákat vethet fel, hogy hiányzik a követéses segítség, olyan szakember hálózat megléte, akik a szociális szférához tartoznának, ismerve az oktatásügyet és az egészségügyi ellátást is. A bölcsődei, óvodai dolgozóknak is alapvetô ismeretekkel kellene rendelkezniük az eltérő fejlődés eseteiről és a szülókkel való együttmúködés lehetőségeiről. (Radványi, 2013, 129.) A tradicionális megközelítés helyett érdemesebb a családközpontút alkalmazni, a családtagokat bevonva a megfigyelési, értékelési munkacsoportokba. Lényeges szempont, hogy a család felismerje érdekeltségeit, prioritásait, eszközeit. Az utóbbi évtize- 
dekben a kutatások hátterében a család kiscsoportként történő elemzése áll, és célként a krízisek negatív következményeinek csökkentése nevezhető meg.

A téma minden területén kiemelendô a folyamatos szupervízió fontossága, melynek megvalósulása sok esetben akadályozott. Végül, de nem utolsósorban említésre méltó a segítő szakemberek saját pszichés jóllétének fenntartása, a segítők mentálhigiénés gondozása. (Radványi, 2013, 131.)

Radványi Katalin könyve rávilágít a fogyatékos gyermekek és családjaik életében jelen lévő érzelmi és materiális problémaforrásokra, hangsúlyt fektetve a szülők lelki megterheltségére és a lehetséges enyhítő faktorokra. Az írásban vizsgált pszichológiai és pedagógiai elméletek csoportosítása, kifejtése segít megfelelő keretbe rendezni a gyermekek és családjaik mindennapi életére ható tényezőket. A könyv megérteti a szülők reakciói mögött húzódó lelki okokat, ezzel elősegítve a pedagógusok munkáját és a családdal való hatékony interakciókat és kommunikációt.

Noha kiváló múvet olvashatunk a szerzőtól, megemlítendő az a tény, hogy az egyes témák nem minden esetben vannak koherensen keretbe rendezve a könyvben, és néhol egyes témakörök közbeékelése kissé zavaró lehet az olvasó számára.

A pedagógusok manapság megnövekedett gyógypedagógia iránti érdeklődése aktuálissá teszi a művet, érthetô nyelvezete miatt is elengedhetetlen kézikönyv lehet a felkészült, tudásukat bővíteni kívánó nevelők számára. Az érintett családoknak szintén fontos tudni a releváns szakirodalmakról, a legújabb kutatásokról, hiszen ezek segítségével enyhíthető gyászfolyamatuk, érthetôvé válhat számukra, hogy az érzelmeik normálisnak tekinthetôk, és a családi dinamikájukban való változás is természetes velejárója a fogyatékos, beteg gyermek nevelésének.

Szakmai szempontból megszívlelendő az ajánlott multidiszciplináris szakemberképzésre való fókuszálás hazánkban, illetve a családcentrikus, empatikus elvek mentén a diagnoszták esetleges továbbképzése, a pedagógusok gyógypedagógiai szemléletű szakmai oktatása. A könyv ajánlható minden érdeklődô és leendő vagy már gyakorló gyógypedagógus számára is, hiszen szakmailag, tartalmában megfelelőképpen felépített írást olvashatunk Radványi Katalin tollából.

\section{Irodalom}

Bowes J. M., Hayes, A. (1999): Children, Families, and Communities. Contexts and Consequences - Section B: Characteristics of children: effects of disability, ethnicity and gender. University Park Press, Oxford.

Dallos R.,Procter H. (1989): A családi folyamatok interakcionális szemlélete. In Bíró S.- Komlósi P. (szerk.): Családterápiás olvasókönyv, I. kötet, Mérei Ferenc Mentálhigiénés Szolgálat, Budapest.

Farber, B. (1975): Family adaptation to severely mentally retarded children. In Begab, M. J., Richardson, S. A.: The mentally retarded and society: a social science perspective. University Park Press, Baltimore.

Fisman, S., Wolf, L., Ellison, D., Freeman, T. (2000): A longitudinal study of siblings of children with chronic disabilities. Canadian Journal of Psychiatry, 45(4), 369-375.

Gallagher, J. J., Bristol, M. (1989): Families of young handicapped children. In Wang, M. C.-Reynolds, M. C., Walberg, H. J: Handbook of Special Education, 3. Pergamon Press. 295-317.

Gallagher, J. J., Bristol, M. (1992): Families of young handicapped children. In Handbook of Special Education, 3. 295-317.

Gallagher, T. J., Hartung, P. J., Gregory, S. W. (2001): Assessment of a measure of relational communication for doctor-patient interactions. Patient Education and Counseling, 45, 211-218.

Hannah, M. E., Midlarsky, E. (2005): Helping by Siblings of Children with Mental Retardation. American Journal on Mental Retardation, 110(2), 8799.

Hebb, D. O. (1949): The organization of behavior. Wiley, New York. Hebb, D. O. (1994): A pszichológia alapkérdései. Gondolat-Trivium, Budapest.

Kirk, S. A., Gallagher, J. J., Anastasiow, N. J. (1997): Educating Exceptional Children (8th ed.). Houghton Mifflin Company, Boston.

Komlósi P. (1989): A család támogató és károsító hatásai a családtagok lelki egészségére. In Gerevich 
J. (szerk.): Közösségi mentálhigiéné. Gondolat, Budapest. 21-55.

Krause, M. P. (2005): Psychologische Aspekte der Diagnosemitteilung. In Stahl, B-Irblich, D. (Hrsg.): Diagnostik bei Menschen mit geistiger Behinderung. Ein interdisziplinäres Handbuch. Hogrefe, Göttingen. 136-156.

Kulcsár Zs. (1996.): Korai személyiségfejlõdés és énfunkciók. Akadémiai Kiadó, Budapest.

McKeith, R. (1973): The feelings and behavior of parents of handicapped children. Developmental Medicine and Child Neurology, 15, 524-527

Radványi K. (1999): „Ki vagyok én?” Szempontok értelmileg akadályozott gyermekeke önismeretének fejlesztéééber. Bárczi Gusztáv Gyógypedagógiai Tanárképzõ Fõiskola, Budapest.

Sarimski, K. (2003): Entwicklungspsychologie genetischer Syndrome. Hogrefe. Schuntermann, P. (2009): Growing up with a developmentally challenged brother or sister: a model for engaging siblings based on mentalizing. Harvard Review of Psychiatry, 17, 5, 297-314.

Stoneman, Z. (2005): Siblings of Children with Disabilities: Research Themes. Mental Retardation, 43, 5, 339-350

Wolf, L.-Fisman, S.-Ellison, D.-Freeman, T. (1998): Effect of sibling perception of differential parental treatment in sibling dyads with one disabled child. Journal American Academy of Child and Adolescents Psychiatry, 37, 12, 1317-1325.

Zwaigenbaum, L.-Bryson, S.-Rogers, T.-Roberts, W.-Brian, J.-Szatmári, P. (2005): Behavioral manifestations of autism in the first year of life. International Journal of Developmental Neuroscience, 23, 2-3, 143-152. 